\title{
Article \\ Jerusalem Artichoke as a Strategic Crop for Solving Food Problems
}

\author{
Alexandra Anatolyevna Manokhina ${ }^{1}$ (D), Alexey Semyonovich Dorokhov ${ }^{1}$, Tamara Petrovna Kobozeva ${ }^{1}$, \\ Tatiana Nikolaevna Fomina ${ }^{1, *}$ (D) and Viktor Ivanovich Starovoitov ${ }^{2}$
}

check for

updates

Citation: Manokhina, A.A.;

Dorokhov, A.S.; Kobozeva, T.P.; Fomina, T.N.; Starovoitov, V.I. Jerusalem Artichoke as a Strategic Crop for Solving Food Problems. Agronomy 2022, 12, 465. https:// doi.org/10.3390/agronomy12020465

Academic Editors: Riccardo Testa Giuseppina Migliore,

Giorgio Schifani and József Tóth

Received: 17 January 2022

Accepted: 10 February 2022

Published: 13 February 2022

Publisher's Note: MDPI stays neutral with regard to jurisdictional claims in published maps and institutional affiliations.

Copyright: (C) 2022 by the authors. Licensee MDPI, Basel, Switzerland. This article is an open access article distributed under the terms and conditions of the Creative Commons Attribution (CC BY) license (https:// creativecommons.org/licenses/by/ $4.0 /)$.
1 Moscow Timiryazev Agricultural Academy, Russian State Agrarian University, 127550 Moscow, Russia; alexman80@list.ru (A.A.M.); ikg@rgau-msha.ru (A.S.D.); tkobozeva@rgau-msha.ru (T.P.K.)

2 Russian Potato Research Center, 140060 Moscow, Russia; mail@vniikh.com

* Correspondence: tfomina67@mail.ru

Abstract: Jerusalem artichoke is a staple for the raw material base of healthy food, beverages, feed, medicine, and fuel, in addition to being the source of its herbage and tubers. The choice of conditions for cultivating a variety depends on the purpose or direction for the crop and the products obtained from it. This research involved laboratory and on-farm studies of 16 Jerusalem artichoke varieties of different maturity groups cultivated on sod-podzolic sandy loam soils to determine their suitability for further use in feed production. The list of varieties in question is presented in this work. The gross yield of tubers obtained from varieties with early leaf wilting was 33.1-51.1 $\mathrm{t} / \mathrm{ha}$, whereas that from varieties with late leaf wilting was 14.4-43.9 $\mathrm{t} / \mathrm{ha}$. The total yield of Jerusalem artichoke raw biomass was 36.8-98.1 t/ha. Moreover, early varieties had a dominant mass of tubers in the total feed value structure $(68 \%)$, whereas herbage mass $(59 \%)$ prevailed in the total feed value structure of varieties with late leaf wilting. The highest total solids in tubers (25.0-26.4\%) were found in varieties Korenevskiy, Novost VIRa, and Blank Brekos; whereas high inulin content was found in varieties Dieticheskiy, Kaluzhskiy, Korenevskiy, Nakhodka, Novost VIRa, and Blank Brekos. The aggregate feed value amounted to 37.0-103.4 thousand MJ/ha of metabolized energy; this exceeded energy production costs on properly selected varieties by two- to three-fold. The data obtained can be useful for growers in the introduction and evaluation of Jerusalem artichoke varieties to be cultivated for further usage and processing, including fodder purposes.

Keywords: Jerusalem artichoke; tubers; herbage; quality of tubers; feed value

\section{Introduction}

Jerusalem artichoke has recently received increased attention due to its remarkable properties as a strategic crop for multiple uses in solutions to food and feed problems. The large amounts of inulin, fructose, and pectin enhance the value chain of Jerusalem artichoke (Helianthus tuberosus L.). The content of inulin, a polysaccharide found in Jerusalem artichoke tubers, is $10-25 \%$ of the tuber weight. Moreover, Jerusalem artichoke herbage is characterized by a rich carbohydrate complex (fructose, glucose, sucrose, fructosides, etc.), enabling $83.2 \mathrm{~L}$ of alcohol per ton to be obtained. The crop solids contain up to $17 \%$ protein with a balanced amino acid composition. Several studies have shown that the introduction of Jerusalem artichoke inulin and bioethanol waste products into feed composition can increase the economic efficiency of animal husbandry and ensure the environmental safety of animal products [1-3]. In this context, Jerusalem artichoke has made its way into European and American diets, and production systems for drugs, food, and alcohol. At present, the global growing area under Jerusalem artichoke is about 2.5 million hectares; in France, for example, it is almost equal to the area under potatoes, i.e., over 250,000 hectares, with a total yield of 7.5 million tons. Canada produces 13 million tons of Jerusalem artichoke. In the USA, it is known as topinambour (earth apple) and 
sunchoke [4]. Despite an arable land shortage, China has intensively been developing the production of Jerusalem artichoke. Furthermore, many countries grow Jerusalem artichoke as a vegetable crop (Italy, Spain, and Germany), and small amounts are imported into Russia [5-7]. In the Russian Federation, the area under the crop is still insignificantabout 3000 hectares of mechanized production and a small territory in family household orchards and vegetable gardens. Jerusalem artichoke is mainly cultivated in the regions of Nizhny Novgorod, Lipetsk, Tver, Ryazan, Tula, Ulyanovsk, Kostroma, Volgograd, Omsk, Bryansk, Moscow, Saratov, and Yaroslavl, the Republic of Chuvashia, and the Krasnodar and Stavropol territories [8,9].

The yield of Jerusalem artichoke and products obtained varies greatly with the growing conditions and ecological and geographical surroundings, particular those affecting the length of the growing season [10-15]. In northern latitudes, the length of the growing season becomes shorter, and changes in the photoperiod for development and the growing season gradually increase [16,17]. Global experience of Jerusalem artichoke cultivation has shown that this crop does well in areas with a temperate climate, and it has the potential to be included in rotation as an alternative crop within the traditional cropping systems [18].

However, to increase their efficiency, and to cope with challenging climate adversities and economic risks, farmers must make a reasonable choice of a suitable variety that satisfies all requirements of soil and climatic conditions. In addition, it must also be considered that the choice of growing environment for a variety depends on its purpose or the manner in which the crop and its products are to be used. Several studies have shown that cultivation of any variety that is not suitable for the local conditions leads to low-quality products and poor plant performance [17,19-21]. Hence, the geographic location where the Jerusalem artichoke variety is grown is of decisive importance to ensure maximum gain $[17,22]$. The total plant leaf area of each variety is the indicator of the variety's photosynthetic activity and productivity $[17,22-24]$. These figures depend on the complex interactions between the variety in question, the season, the ecological and geographical conditions of cultivation, and the climatic conditions $[17,24,25]$. Varietal cultural practices are also of great importance. While carrying out ecological-geographical analysis of a variety, it is necessary to evaluate the given variety according to such parameters as influence of soil composition and structure on variety productivity and tuber quality, including biochemical content [21,26-28].

Noteworthy scientific and technical achievements in the 20th century have enabled the significant expansion of the diversity of plant applications, both for food and processing into foodstuffs, medicine, and alternative energy sources.

Despite numerous studies, the range of Jerusalem artichoke continues to be constrained because the demand for this valuable crop, as a source of inulin, fructose, and pectin, is not yet sufficient. Investments in the construction of enterprises for Jerusalem artichoke processing to obtain inulin have intensified, but the lack of raw materials at an industrial scale, in addition to the lack of devices for mechanized cultivation, pose risks to the implementation of these investment projects within the national agricultural base. Nonetheless, Jerusalem artichoke is thought to resemble potato in terms of a number of technological parameters [1,29-31]. In view of this, the introduction of mechanized cultivation technology for Jerusalem artichoke will provide opportunities for large-scale commercial processing of the crop, in order to produce raw materials for the production of innovative and healthy food products, animal feed, bioethanol, and fuel pellets.

In this research, laboratory and field studies were conducted of 16 Jerusalem artichoke varieties on sod-podzolic sandy loam soils, with the aim of determining their suitability in feed production applications.

The following tasks were completed: (1) technological characteristics of Jerusalem artichoke varieties were analyzed; (2) the features of the yield formation, plant structure components, and tuber quality indicators, in addition to crop processing products, were investigated; and (3) the economic and energy efficiency of the technology used in Jerusalem artichoke cultivation was assessed. 
We believe that crop producers will find our results effective in the introduction and evaluation of Jerusalem artichoke varieties to be cultivated for further usage and processing, including for fodder purposes. Producers may benefit from our practices and discoveries as they grow and experiment with Jerusalem artichoke on their own farm units.

\section{Research Conditions, Technique, and Methodology}

\subsection{Soils of Test Plots}

The Moscow Region is a constituent entity of the Russian Federation. It belongs to the Central Federal District. Despite a wide range of soil compositions and fertility levels, and precipitation amounts and degrees of uniformity, the middle part of the territory of Russia (including the Central, Central Black Earth, and Middle Volga regions, Western Siberia, and the Urals mountainous region) is commonly characterized by a relatively moderate background of infectious load, and can be considered to be a suitable region for establishing private production of high-quality Jerusalem artichoke for seeds and forage $[19,20]$.

The research results were obtained based on laboratory-field experiments established on soils typical of the Non-Chernozem zone of the Russian Federation in terms of their agriphysical and agrichemical properties.

At the "Korenevo" Experimental Center test site, the soil for field trials for evaluating Jerusalem artichoke varieties can be described (Table 1) as sod-low podzolic sandy loam with high exchangeable and hydrolytic acidity $(\mathrm{pHKCl}=4.4-4.9 ; \mathrm{Hg}=3.3-4.8 \mathrm{mg}$. eq/100 g of soil); low quantity of absorbed bases and saturation degree $(\mathrm{S}=1.5-3.9 \mathrm{mg}$. eq/100 g of soil; $\mathrm{V}=31.0-46.8 \%$ ); high content of mobile phosphorus (267-354 mg/ $\mathrm{kg}$ of soil); below average content of exchangeable potassium (95-136 mg/ $\mathrm{kg}$ of soil); and low humus content (1.6-1.9\% humus).

Table 1. Agrochemical characteristics of sod-slightly podzolic sandy loam soils before field trial establishment.

\begin{tabular}{|c|c|c|c|c|c|c|c|c|}
\hline \multirow{2}{*}{ Years } & \multirow{2}{*}{$\mathrm{pH}_{\mathrm{KCl}}$} & $\mathrm{Hg}$ & $S$ & $\begin{array}{l}\text { Sum of } \\
\mathrm{N}-\mathrm{NO}_{3} \\
\mathrm{~N}-\mathrm{NH}_{4}\end{array}$ & $\mathbf{P}_{2} \mathrm{O}_{5}$ & $\mathrm{~K}_{2} \mathrm{O}$ & $\mathbf{V}$ & Humus \\
\hline & & \multicolumn{2}{|c|}{$\underset{\text { Soil }}{\text { mg-eq/100 g }}$} & mg/kg Soil & \multicolumn{2}{|c|}{$\begin{array}{c}\mathrm{mg} / \mathrm{kg} \text { Soil } \\
\text { (According to Kirsanov) }\end{array}$} & \multicolumn{2}{|c|}{$\%$} \\
\hline 2014 & 4.7 & 3.7 & 2.4 & 23.3 & 264 & 127 & 39.3 & 1.8 \\
\hline 2015 & 4.7 & 3.6 & 2.2 & 16.5 & 280 & 100 & 37.9 & 1.7 \\
\hline 2016 & 4.9 & 3.6 & 2.5 & 24.5 & 342 & 64 & 41.0 & 1.7 \\
\hline
\end{tabular}

\subsection{Agrometeorological Conditions for Research Conducting}

We carried out the research in the period of 2014-2016 at the test plot of the "Korenevo" Experimental Center; on-the-farm tests were conducted in 2016 at LLC "Kaluga Agro" of the Dzerzheyunskiy district of the Kaluga region.

The meteorological conditions during the years of the research are presented in Figure 1.

The hydrothermal coefficient according to Selyaninov (HTC), the value of which is closely related to the yield level, reflects the broadest characteristic of weather conditions. The coefficient is determined by dividing the precipitation amount of the calculated period by the number of effective $\left(10^{\circ} \mathrm{C}\right)$ temperatures, reduced by 10 times over the same period. A decrease in yield was observed at HTC $\leq 0.8$ during the period of tuberization. When HTC was more than 3.0, yield decreases resulted from moisture excess [32]. 


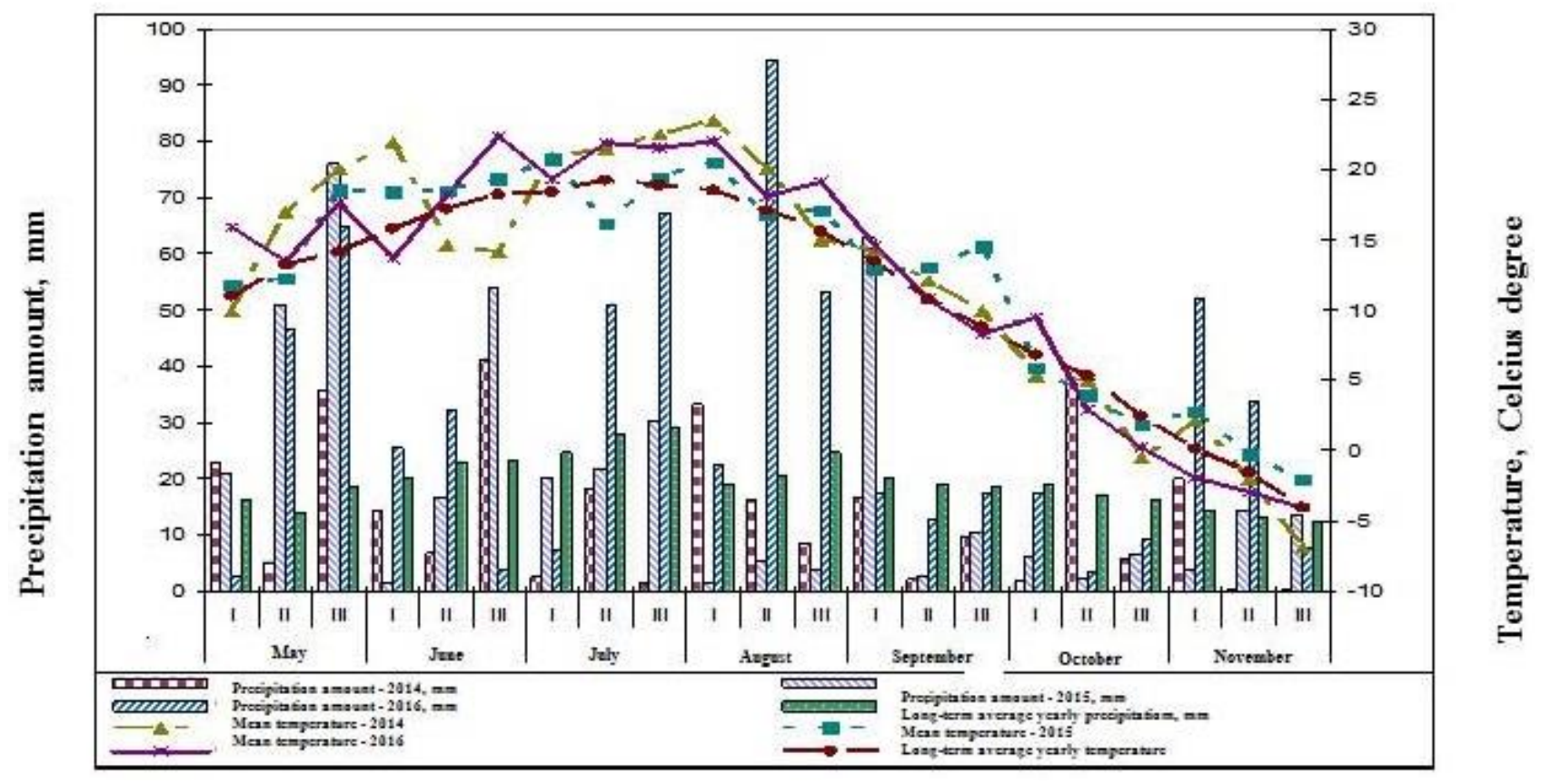

Figure 1. Meteorological conditions during the research years (2014-2016). (Data taken from the Korenevo meteorological station, Lyuberetskiy district of the Moscow region).

Agrimeteorological growing season conditions for the period of 2014-2016 were generally satisfactory for Jerusalem artichoke growth, development, and productivity. The average air temperature of the growing season in 2014 was $12.4{ }^{\circ} \mathrm{C}$ (in $2015-12.5^{\circ} \mathrm{C}$; in $2016-12.4^{\circ} \mathrm{C}$ ), with a norm of $11.4^{\circ} \mathrm{C}$. Total precipitation of the growing season in 2014 was $300.2 \mathrm{~mm}$ or $73.2 \%$ (in $2015-425 \mathrm{~mm}$ or $103.7 \%$; in $2016-642.3 \mathrm{~mm}$ or $156.6 \%$ ) with a norm of $410.1 \mathrm{~mm}$. The HTC in 2014 was 0.97 (dry), in 2015 it was 1.61 (wet), and in 2016 it was 2.03 (very wet).

\subsection{Research Conditions \\ Objects of the Research}

Sixteen Jerusalem artichoke varieties of different maturity groups were studied: early ripening variety - Skorospelka (Russian Federation); mid-early ripening varietiesVylgortskiy (RF); Dieticheskiy (RF), Kaluzhskiy (RF), Korenevskiy (RF), Nadezhda (RF), Nakhodka (RF), Podmoskovniy (RF), Sireniki (RB), Blank Brekos (France), Violet de Rense (France); late ripening varieties-Interest (RF), Interest 21 (RF), Novost VIRa (RF), Tadzhikskiy Krasniy (USSR), Spindle (Germany).

The following operations were performed: (a) 2-track disk harrowing of green manure crops (vetch + oats) in the first ten-day period of August of the previous year; (b) under winter plowing (the first ten-day period of October) with a spinner-type plow without a plough-point to a depth of $18-20 \mathrm{~cm}$; (c) spring continuous cultivation with harrowing (second and third ten-day periods of April) using a solid cultivator with a crust buster attached; and (d) ridge-forming tillage using a row cultivator with fertilizer dispensers. Seed preparation involved calibration and selection of healthy tubers. Seed tubers having a transverse diameter of $25-40 \mathrm{~mm}$ were planted to a depth of $8-10 \mathrm{~cm}$ on the test plot using a potato planter with manual tuber feeding.

Field experiments were carried out during the 2014, 2015, and 2016 growing seasons at the "Korenevo" Experimental Center, and LLC "Kaluga Agro" of the Dzerzheyu district of the Kaluga region. Plots of the different varieties were arranged in a randomized block design with four replications. The plant density was 25,000 units $/$ ha $(75 \times 53 \mathrm{~cm})$. The plot area was $20 \mathrm{~m}^{2}$. Jerusalem artichoke planting was undertaken on 27-30 April each research year. 
Two fertilization bands of azofoska (N60P60K60) were applied locally in May using a row-crop cultivator with fertilizer dispensers. The bands were about $4 \mathrm{~cm}$ wide. They were placed $4-5 \mathrm{~cm}$ on each side from the ridge center and 3-4 $\mathrm{cm}$ below the tuber row. Crop tending included two inter-row cultivations with hilling using a row cultivator in MayJune; the first was performed at the pre-emergence stage and the second was conducted at the post-emergence stage. Weed control was performed using a spray hose with herbicides (the first treatment with Zenkor at a rate of $600 \mathrm{~g} / \mathrm{ha}+$ Titus $30 \mathrm{~g} / \mathrm{ha}+$ Trend $200 \mathrm{~mL} / \mathrm{ha}$ ), in May.

\subsection{Methodology of Field Experiments, Observations, Analyzes and Reports}

Trial establishment, records and observations were carried out in accordance with the requirements of the field experiment methodology [33] and the program and methodology for evaluating Jerusalem artichoke varieties in test nurseries [34].

Agrochemical soil parameters were analyzed during field reconnaissance in accordance with the methodology for soil sample selection in elementary field areas to apply fertilizers differentially. Agrochemical characteristics of the soil before fertilization were determined as follows: humus-according to Tyurin (National State Standard 26,213-91); $\mathrm{P}_{2} \mathrm{O}_{5}$ and $\mathrm{K}_{2} \mathrm{O}$-according to Kirsanov (National State Standard 26,207-91); pH (salt) potentiometrically (National State Standard 26,483-85); hydrolytic acidity-according to Kappen, modified by the Pryanishnikov Institute of Agrochemistry (National State Standard 26,212-91).

The yield report was compiled manually by weighing herbage (tubers) from 4-8 plants: the first was at the flowering phase of varieties with early leaf wilting; the second was at the end of October.

The following factors were determined in the cropping samples at the flowering phase of early varieties according to all variants of the experiment:

1. Indicators of herbage forage qualities: maximum plant height, $\mathrm{cm}$; leaf area, $\mathrm{m}^{2} / \mathrm{plant}$; herbage amount, $t$, in terms of 1 hectare; nutritional value of the feed in megajoules of metabolizable energy.

2. Productivity of tubers, $t$ /ha and indicators of tuber quality [35]: crop marketability, tuber shape, skin color, skin surface, dry matter content using the thermostat-weight method; nitrate content using the ionometric method (with a nitratomar-tester); the content of soluble and insoluble substances using the hot water diffusion method; and carbohydrate content, \%, using the method of liquid chromatography.

3. Tuber qualities for fresh consumption (at the flowering phase of early varieties): Technological qualities of flesh: degree of sweetness; flesh juiciness. Taste qualities of raw flesh on-scale: 1-bad (unpleasant, bitter); 3-flat; 5-satisfactory (including sweetish); 7-good; 9-excellent. Flesh hardness on-scale: 1-rough; 2-hard; 3moderately hard; 4-soft (tend). Smell on-scale: 1-not typical of Jerusalem artichoke with an unpleasant odor; 3-not typical of Jerusalem artichoke; 5-poorly expressed, satisfactory (with a slight presence of foreign odor); 7-poorly expressed, rather good, without foreign odors; 9-pleasant, characteristic of Jerusalem artichoke, without foreign odors. Flesh browning on-scale: 1-browning very heavily; 3-browning strongly over the entire surface; 5-browning moderately; 7-browning slightly; 9-flesh does not turn brown.

4. Bioenergetic efficiency of technological method combinations according to the JSC Information and publishing center PATENT methodology [36] and the bioenergy assessment method [37].

5. Analysis of variance of the data obtained according to Dospekhov B.A. [33].

The research reliability was confirmed by the accepted methodology for conducting a 3-year field study and statistical processing results, obtained by methods of variance, correlation, and regression analyses. 


\section{Research Results}

\subsection{Record of Jerusalem Artichoke Tubers' Yield and Quality}

For each variety, tuber yield was registered in two periods (Table 2): the flowering phase of varieties with an early period of top wilting (early September) and the phase of budding-flowering of varieties with a late period of top wilting (the third ten-day period of October).

Table 2. Productivity of Jerusalem artichoke tubers (2014-2016), t/ha.

\begin{tabular}{|c|c|c|c|c|c|c|c|}
\hline \multirow{2}{*}{ Sl. № } & \multirow{2}{*}{ Variety } & \multicolumn{3}{|c|}{ September } & \multicolumn{3}{|c|}{ October } \\
\hline & & $>30 \mathrm{~mm}$ & $<30 \mathrm{~mm}$ & total & $>30 \mathrm{~mm}$ & $<30 \mathrm{~mm}$ & total \\
\hline \multicolumn{8}{|c|}{ Varieties of early leaf wilting ("early varieties") } \\
\hline 1 & Vylgortskiy & 1.9 & 11.5 & 13.4 & 36.0 & 1.5 & 37.5 \\
\hline 2 & Diyeticheskiy & 40.1 & 3.4 & 43.5 & 40.1 & 6.0 & 46.1 \\
\hline 3 & Nadezhda & 11.8 & 29.0 & 40.8 & 41.2 & 4.8 & 46.0 \\
\hline 4 & Nakhodka & 21.2 & 2.1 & 23.3 & 50.3 & 0.8 & 51.1 \\
\hline 5 & Podmoskovniy & 24.4 & 2.1 & 26.5 & 43.5 & 0.9 & 44.4 \\
\hline 6 & Sireniki & 9.3 & 13.8 & 23.1 & 31.1 & 15.8 & 46.9 \\
\hline 7 & Skorospelka & 16.7 & 2.7 & 19.4 & 47.2 & 3.5 & 50.7 \\
\hline 8 & Blank Brekos & 27.1 & 3.7 & 30.8 & 1.9 & 31.2 & 33.1 \\
\hline \multicolumn{2}{|c|}{ Group average } & - & - & 27.6 & - & - & 44.5 \\
\hline & $\mathrm{LSD}_{05}$ & - & - & 9.66 & - & - & 5.83 \\
\hline \multicolumn{8}{|c|}{ Varieties of late leaf wilting ("late varieties") } \\
\hline 9 & Interes & 6.3 & 9.5 & 15.8 & 19.3 & 7.8 & 27.1 \\
\hline 10 & Interes 21 & 7.0 & 6.6 & 13.6 & 17.7 & 17.8 & 35.5 \\
\hline 11 & Kaluzhskiy & 2.6 & 7.5 & 10.1 & 12,3 & 7.1 & 19.4 \\
\hline 12 & Korenevskiy & 31.7 & 4.2 & 35.9 & 33.0 & 9.9 & 42.9 \\
\hline 13 & Novost VIRa & 0.6 & 11.5 & 12.1 & 24.7 & 0.5 & 25.2 \\
\hline 14 & Tadzhikskiy & 5.4 & 3.9 & 9.3 & 22.5 & 0.9 & 23.4 \\
\hline 15 & $\begin{array}{l}\text { Violet de } \\
\text { Rense }\end{array}$ & 0.0 & 6.0 & $6 ., 0$ & 6.3 & 8.1 & 14.4 \\
\hline 16 & Shpindle & 0.0 & 8.5 & 8.5 & 14.3 & 29.6 & 43.9 \\
\hline \multicolumn{2}{|c|}{ Group average } & - & - & 13.9 & - & - & 29.0 \\
\hline & $\mathrm{LSD}_{05}$ & - & - & 8.79 & - & - & 10.08 \\
\hline \multicolumn{2}{|c|}{ Total average } & - & - & 20.8 & - & - & 36.7 \\
\hline & $\mathrm{LSD}_{05}$ & - & - & 11.49 & - & - & 11.30 \\
\hline
\end{tabular}

Being harvested at the end of August or at the beginning of September, early varieties produced, on average, 69\% of marketable tubers, whereas late varieties produced, on average, only $48 \%$ of marketable tubers. However, harvesting of early varieties in the third ten-day period of October resulted in $82 \%$ of marketable tubers, and late varieties produced $65 \%$ of marketable tubers (Figure 2 ). 


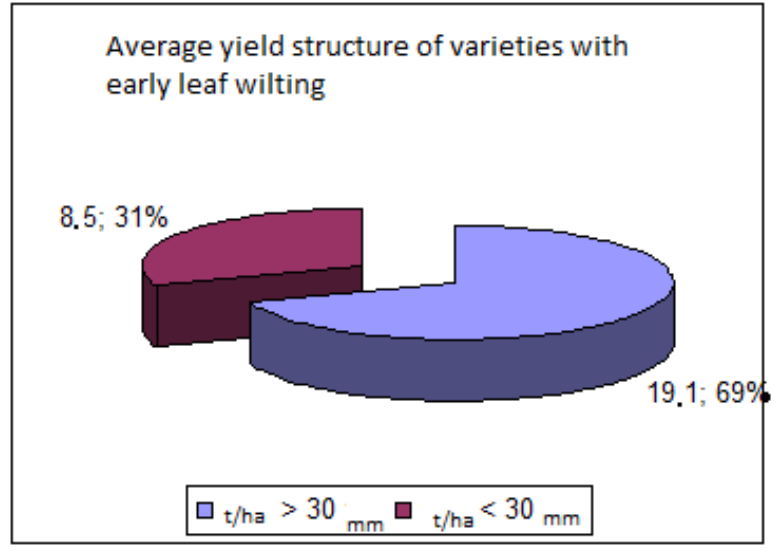

Average yield structure of varieties with late leaf wilting

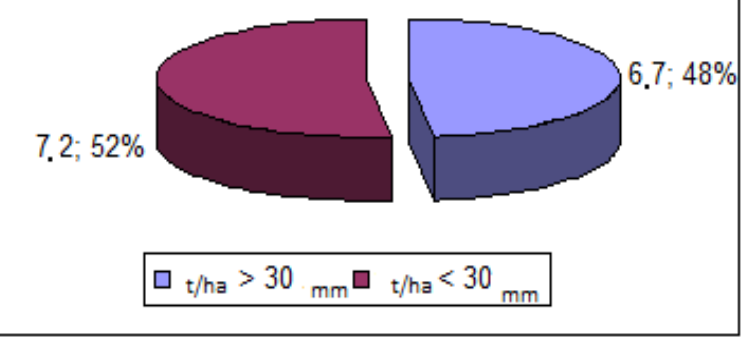

(a)
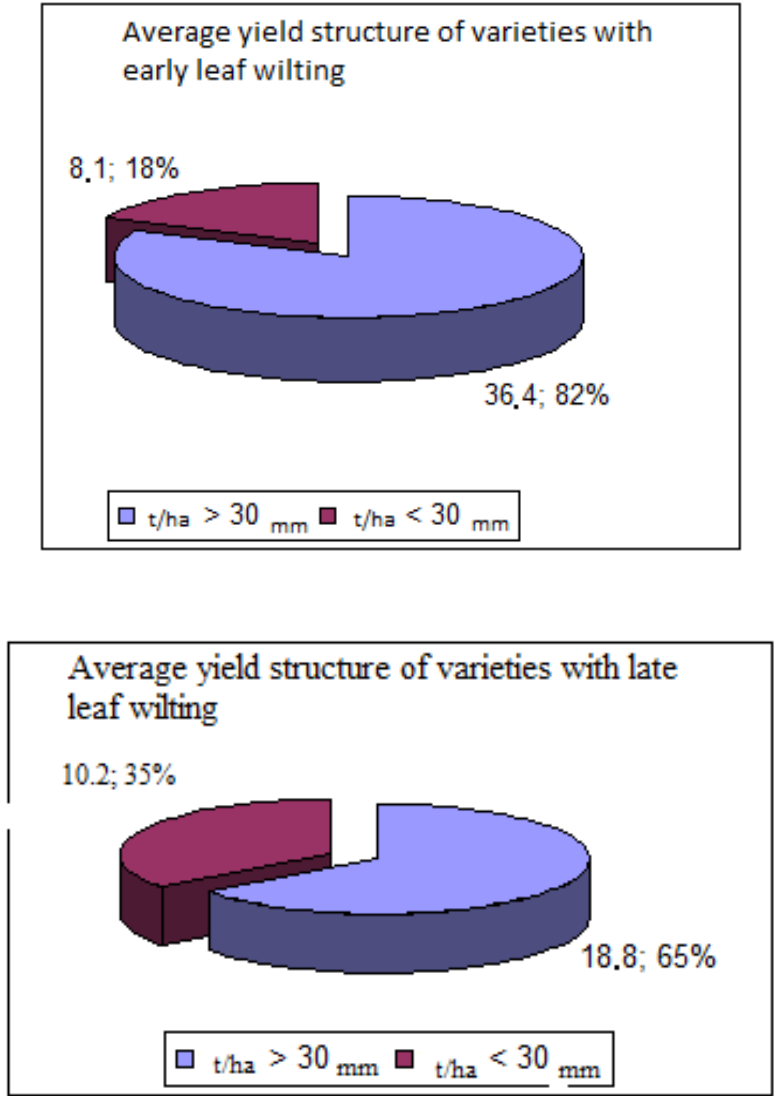

(b)

Figure 2. Yield structure of tubers according to leaf wilting groups. (a) Harvesting in late Augustearly September; (b) harvesting in the third ten-day period of October.

\subsection{The Value of Jerusalem Artichoke as a Forage Crop}

Expressed in megajoules of metabolizable energy per 1 ha, the total productivity of various Jerusalem artichoke varieties grown on sod-podzolic sandy loam soils under the conditions of the "Korenevo" Experimental Center, Lyuberetskiy District, Moscow Region, is shown Table 3 and Figure 3.

Table 3. Gross productivity of Jerusalem artichoke (green weight for foliage + tubers), (2014-2016).

\begin{tabular}{|c|c|c|c|c|c|c|c|}
\hline \multirow[b]{2}{*}{ S1. № } & \multirow[b]{2}{*}{ Variety } & \multicolumn{3}{|c|}{ Yields, t/ha } & \multicolumn{3}{|c|}{ Nutritional Feed Value, Thous., MJ/ha } \\
\hline & & $\begin{array}{c}\text { Herbage } \\
\text { (First } \\
\text { Ten-Day } \\
\text { Period of } \\
\text { September) }\end{array}$ & $\begin{array}{l}\text { Tubers } \\
\text { (Third } \\
\text { Ten-Day } \\
\text { Period of } \\
\text { October) }\end{array}$ & Overall & $\begin{array}{c}\text { Herbage } \\
\text { (First } \\
\text { Ten-Day } \\
\text { Period of } \\
\text { September) }\end{array}$ & $\begin{array}{l}\text { Tubers } \\
\text { (Third } \\
\text { Ten-Day } \\
\text { Period of } \\
\text { October) }\end{array}$ & Total \\
\hline \multicolumn{8}{|c|}{ Varieties of early leaf wilting ("early varieties") } \\
\hline 1 & Vylgortskiy & 24.9 & 13.4 & 38.3 & 19.4 & 40.7 & 60.1 \\
\hline 2 & Diyeticheskiy & 23.6 & 43.5 & 67.1 & 18.4 & 52.7 & 71.1 * \\
\hline 3 & Nadezhda & 42.3 & 40.8 & 83.1 & 32.9 & 51.4 & 84.4 \\
\hline 4 & Nakhodka & 13.5 & 23.3 & 36.8 & 10.5 & 56.8 & 67.3 \\
\hline 5 & Podmoskovniy & 28.4 & 26.5 & 54.9 & 22.1 & 48.2 & 70.4 \\
\hline 6 & Sireniki & 32.5 & 23.1 & 55.6 & 25.3 & 45.9 & 71.3 \\
\hline
\end{tabular}


Table 3. Cont.

\begin{tabular}{|c|c|c|c|c|c|c|c|}
\hline \multirow[b]{2}{*}{ S1. № } & \multirow[b]{2}{*}{ Variety } & \multicolumn{3}{|c|}{ Yields, t/ha } & \multicolumn{3}{|c|}{ Nutritional Feed Value, Thous., MJ/ha } \\
\hline & & $\begin{array}{c}\text { Herbage } \\
\text { (First } \\
\text { Ten-Day } \\
\text { Period of } \\
\text { September) }\end{array}$ & $\begin{array}{l}\text { Tubers } \\
\text { (Third } \\
\text { Ten-Day } \\
\text { Period of } \\
\text { October) }\end{array}$ & Overall & $\begin{array}{c}\text { Herbage } \\
\text { (First } \\
\text { Ten-Day } \\
\text { Period of } \\
\text { September) }\end{array}$ & $\begin{array}{l}\text { Tubers } \\
\text { (Third } \\
\text { Ten-Day } \\
\text { Period of } \\
\text { October) }\end{array}$ & Total \\
\hline 7 & Skorospelka & 37.6 & 19.4 & 56.9 & 29.3 & 52.2 & 81.5 \\
\hline 8 & Blank Brekos & 34.8 & 30.8 & 65.6 & 27.1 & 41.8 & 68.9 \\
\hline \multicolumn{2}{|c|}{ Group average } & 29.7 & 27.6 & 57.3 & 23.1 & 41.7 & 71.8 \\
\hline & $\mathrm{LSD}_{05}$ & 8.51 & 9.66 & 14.23 & 6.63 & 5.25 & 7.24 \\
\hline \multicolumn{8}{|c|}{ Varieties of late leaf wilting ("late varieties") } \\
\hline 9 & Interes & 53.8 & 15.8 & 69.5 & 42.0 & 25.7 & 67.7 \\
\hline 10 & Interes 21 & 25.3 & 13.6 & 38.9 & 22.7 & 32.8 & $55.5^{*}$ \\
\hline 11 & Kaluzhskiy & 31.0 & 10.1 & 41.1 & 24.5 & 25.6 & 50.0 \\
\hline 12 & Korenevskiy & 38.4 & 35.9 & 74.3 & 44.6 & 48.2 & $92.8 *$ \\
\hline 13 & Novost VIRa & 86.0 & 12.1 & 98.1 & 67.7 & 29.6 & $97.3 *$ \\
\hline 14 & Tadzhikskiy & 56.5 & 9.3 & 65.8 & 61.8 & 23.9 & 85.7 \\
\hline 15 & $\begin{array}{l}\text { Violet de } \\
\text { Rense }\end{array}$ & 23.6 & 6.0 & 29.6 & 22.0 & 15.0 & 37.0 \\
\hline 16 & Shpindle & 65.4 & 8.5 & 73.9 & 62.3 & 41.1 & 103.4 * \\
\hline \multicolumn{2}{|c|}{ Group average } & 47.5 & 13.9 & 61.4 & 43.5 & 30.2 & 73.7 \\
\hline & $\mathrm{LSD}_{05}$ & 20.44 & 8.79 & 21.46 & 17.80 & 9.76 & 22.98 \\
\hline \multicolumn{2}{|c|}{ Total average } & 38.6 & 20.8 & 59.3 & 33.3 & 39.5 & 72.8 \\
\hline & $\mathrm{LSD}_{05}$ & 18.01 & 11.49 & 18.32 & 16.84 & 12.11 & 17.06 \\
\hline
\end{tabular}

*: The varieties most suitable for forage production.

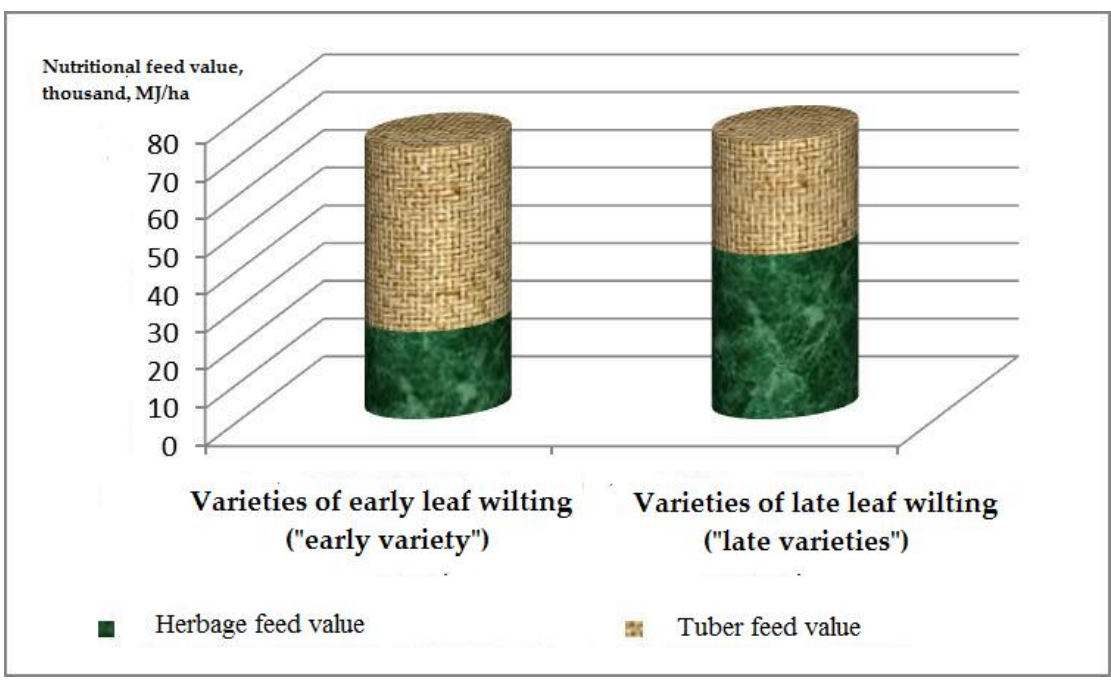

Figure 3. Average feed value of herbage and tubers of Jerusalem artichoke varieties with different leaf wilting periods (average for 2014-2016).

\subsection{Analyses of Tuber Properties of Jerusalem Artichoke Varietal Resources}

Jerusalem artichoke tubers were assessed according to morphological characteristics. Tubers' shape, skin color, and surface were analyzed, and the average length (Figure 4) and outermost transverse diameter of large tubers were estimated (Figure 5). 


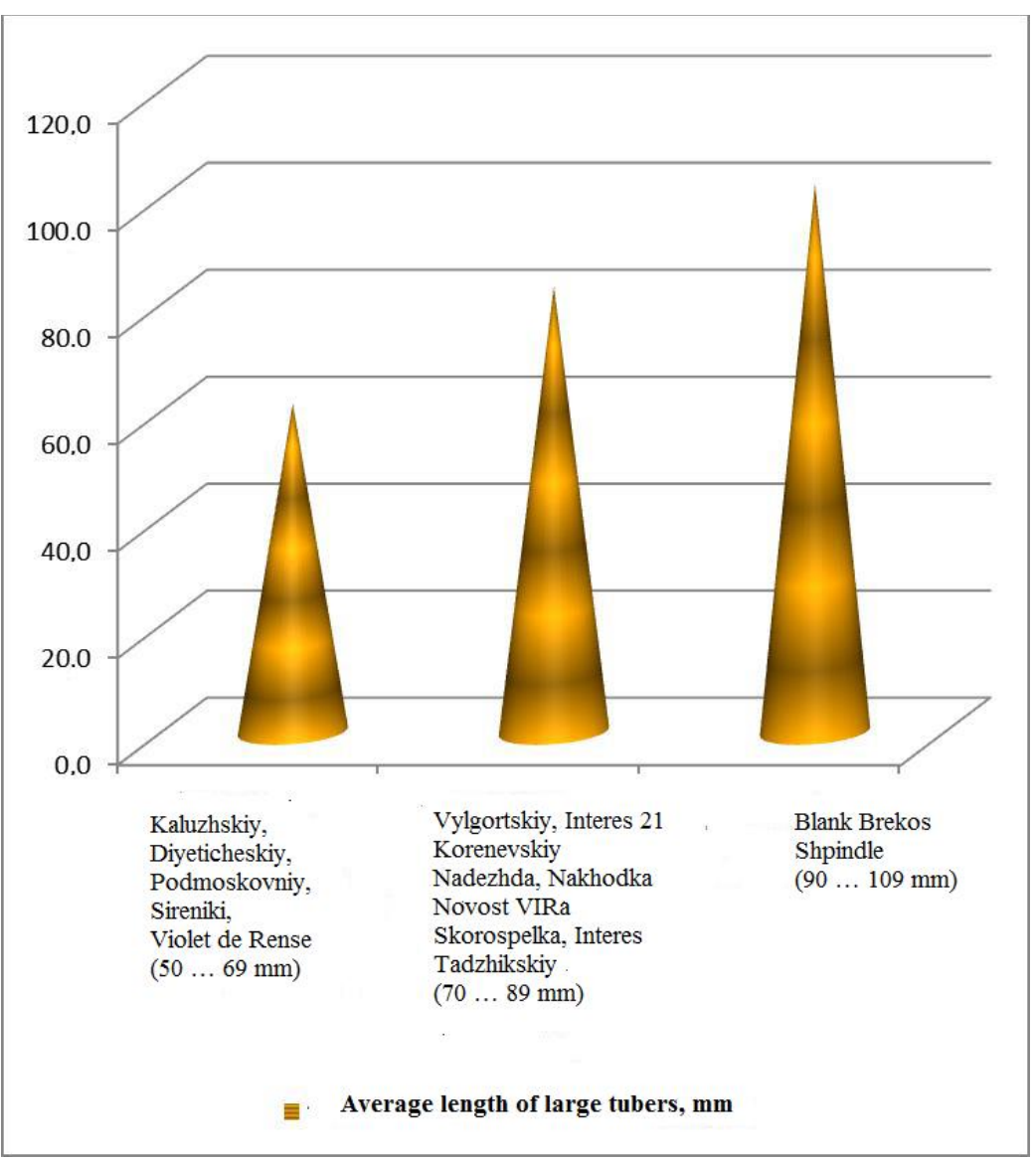

Figure 4. Average length of large tubers, mm (1st ten-day period of September).

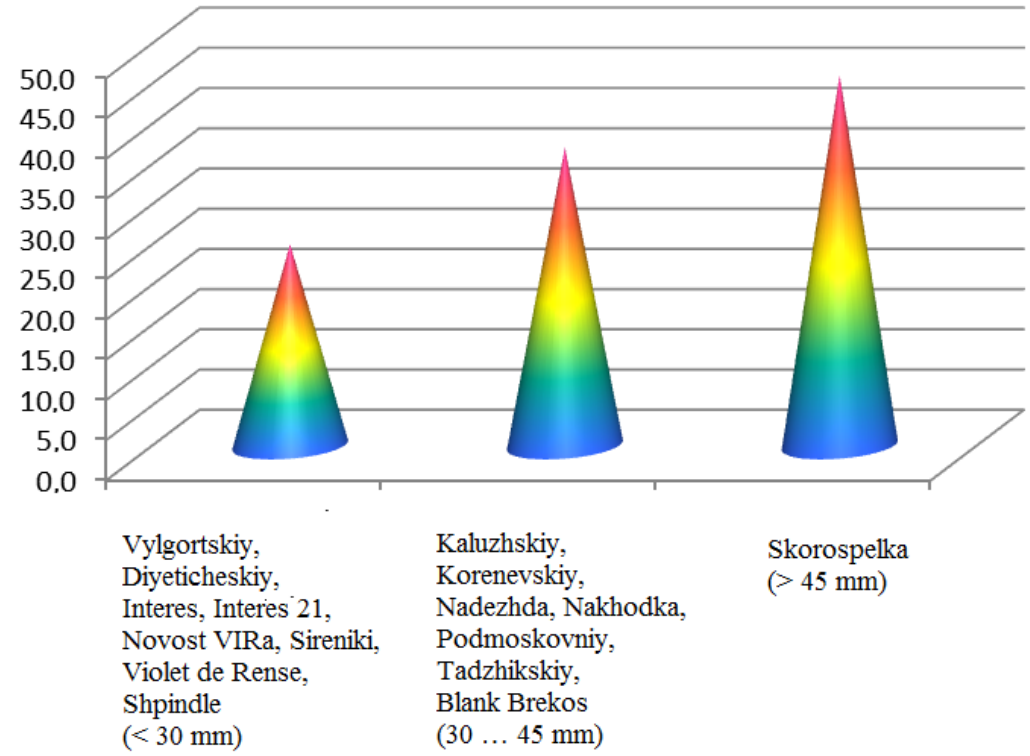

= Outermost transverse diameter of large tubers, $\mathrm{mm}$. (1st ten-day period of September)

Figure 5. Outermost transverse diameter of large tubers, $\mathrm{mm}$ (1st ten-day period of September).

The content of dry matter, total sugars, and inulin in tubers of the studied Jerusalem artichoke varieties was analyzed (Figure 6). 


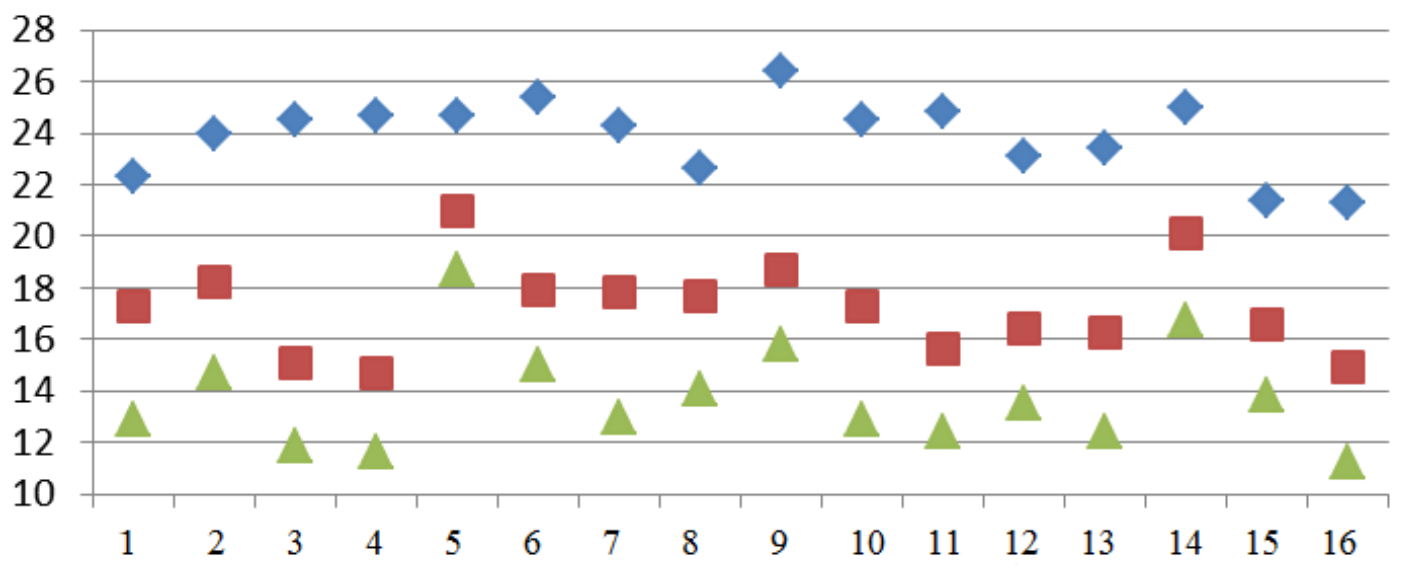
1) Vylgortskiy
2) Diyeticheskiy
5) Kaluzhskiy
6) Korenevskiy
9) Novost VIRa
13) Tadzhikskiy
3) Interes
7) Nadezhda
10) Podmoskovniy
14) Blank Brekos
4) Interes 21
8) Nakhodka
11) Sireniki
15) Violet de Rense
12) Skorospelka
16) Shpindle
Dry matter, \%
Total sugars, $\%$
$\Delta \quad$ Inulun, \%

Figure 6. Content of dry matter, total sugars, and inulin in tubers of the varieties tested.

The technological qualities of raw artichoke tubers were assessed (Figure 7).
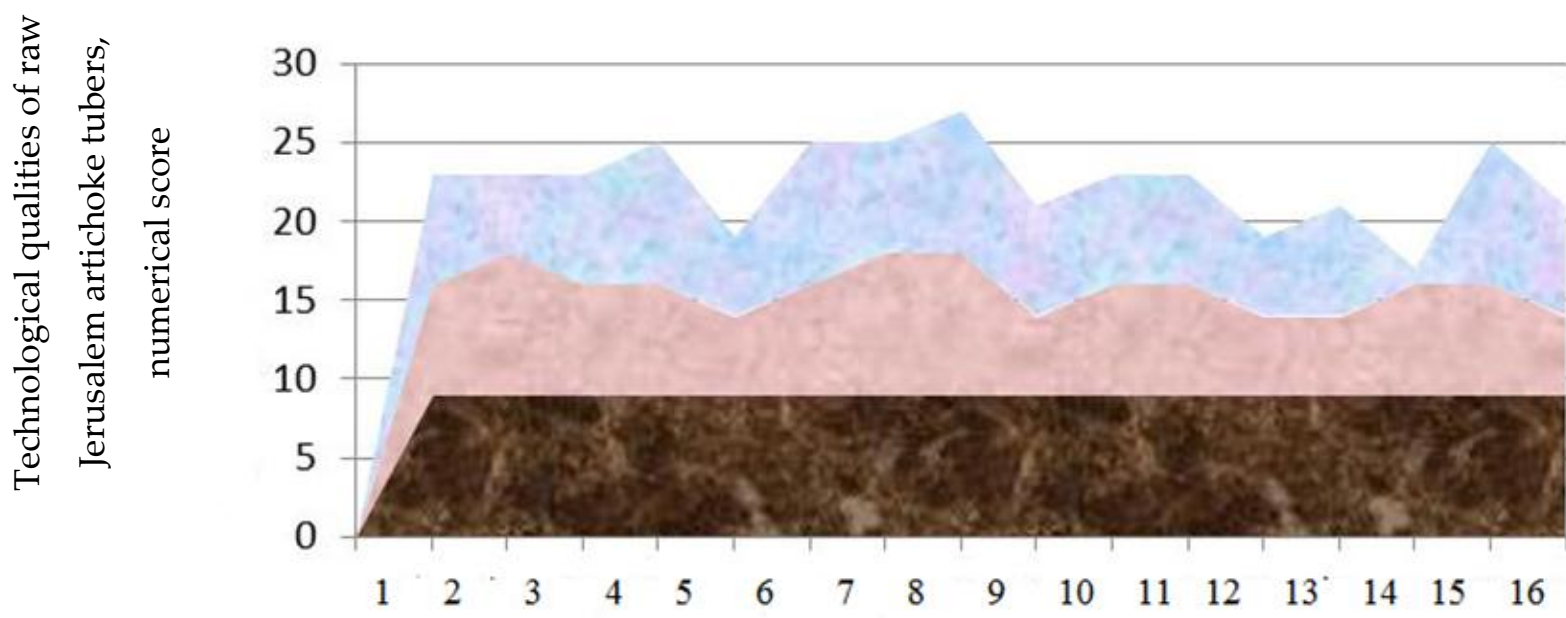

1) Vylgortskiy

2) Diyeticheskiy

5) Kaluzhskiy

6) Korenevskiy

9) Novost VIRa

3) Interes

7) Nadezhda

10) Podmoskovniy

4) Interes 21

8) Nakhodka

11) Sireniki

12) Skorospelka

13) Tadzhikskiy

14) Blank Brekos

15) Violet de Rense

16) Shpindle

Flesh browning Flavour Odor

Figure 7. Technological qualities of raw Jerusalem artichoke tubers, numerical score.

\subsection{Economic and Energy Efficiency of Jerusalem Artichoke Cultivation}

The energy costs and feed values were calculated in megajoules of metabolized energy (Figure 8). 


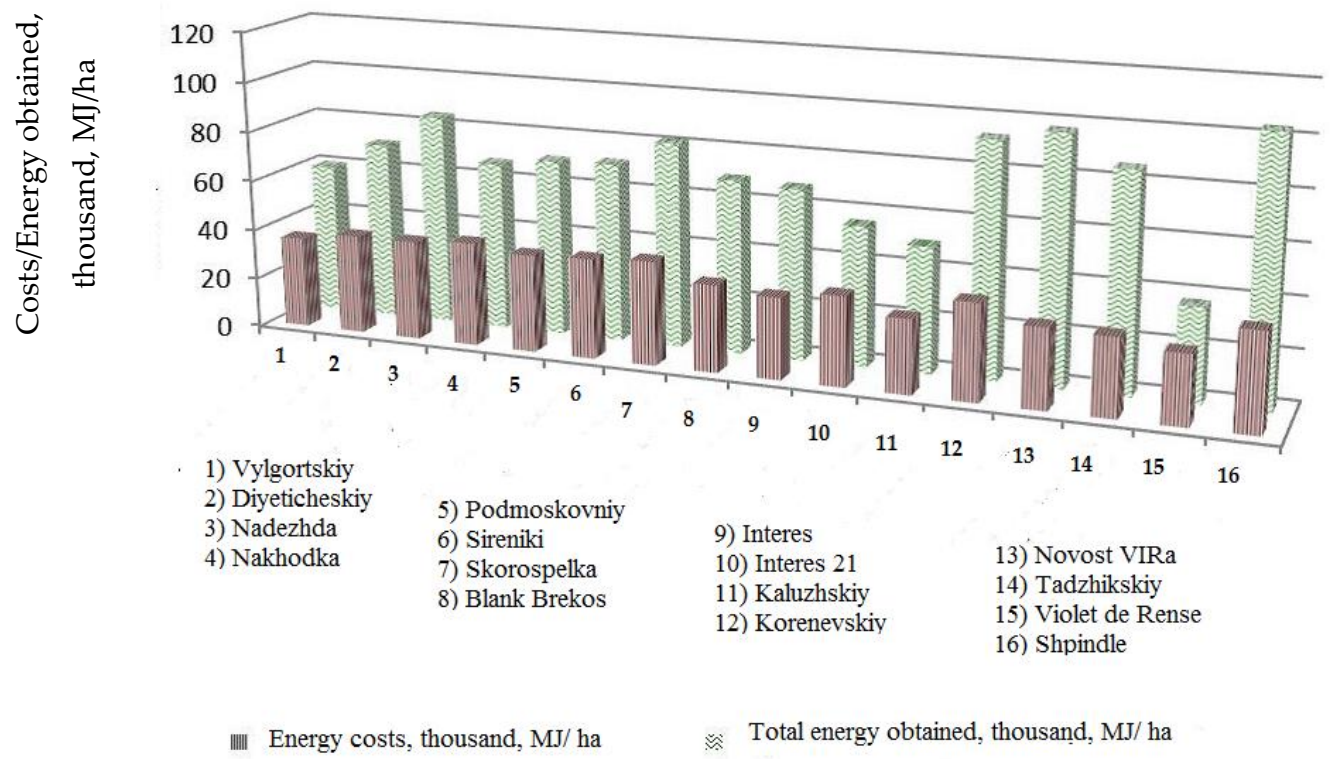

Figure 8. Economic efficiency of Jerusalem artichoke cultivation.

\section{Discussions}

\subsection{Tubers' Yield Report of Jerusalem Artichoke Varieties}

Being harvested in early September (Table 2, Figure 2), the following varieties produced tubers with a fraction of more than $30 \mathrm{~mm}$ in the transverse diameter, thus meeting the requirement of more than 25.0 t/ha: Dieticheskiy $(40.1 \mathrm{t} / \mathrm{ha})$, Korenevskiy $(31.7 \mathrm{t} / \mathrm{ha})$, and Blank Brekos (27.1 t/ha). The varieties Nakhodka (21.2 t/ha), Podmoskovniy (24.4 t/ha), and Skorospelka (16.7 t/ha) produced a yield that was slightly lower than $25 \mathrm{t} / \mathrm{ha}$.

Jerusalem artichoke is a unique crop, all parts of which can be used for benefit (large and small tubers, stems, leaves, flowers, stolons, and roots) $[38,39]$. Therefore, it is advisable to not only take into account the yield of tubers having a coarse fraction of more than $30 \mathrm{~mm}$ in the transverse diameter, but also that of small tubers (less than $30 \mathrm{~mm}$ ). In addition, Jerusalem artichoke total (gross) yield in accordance with the requirement (more than $25.0 \mathrm{t} / \mathrm{ha}$ ) was obtained from the following varieties: Dieticheskiy (43.5 t/ha), Nadezhda (40.8 t/ha), Korenevskiy (35.9), Blank Brekos (30.8 t/ha), and Podmoskovniy (26.5 t/ha).

When the crop was harvested in the third ten-day period of October, the yield of tubers with a fraction of more than $30 \mathrm{~mm}$ in the transverse diameter, in accordance with the requirement (more than $25.0 \mathrm{t} / \mathrm{ha}$ ), was obtained from the following varieties: Nakhodka (50.3 t/ha), Skorospelka (47.2 t/ha), Podmoskovniy (43.5 t/ha), Nadezhda (41.2 t/ha), Dieticheskiy (40.1 t/ha), Vylgortskiy (36.0 t/ha), Korenevskiy (33.0 t/ha), and Sireniki (31.1 t/ha).

Furthermore, all varieties of early leaf wilting met the requirement of producing a total (gross) yield of more than $25.0 \mathrm{t} / \mathrm{ha}$ : Nakhodka (51.1 t/ha), Skorospelka (50.7 t/ha), Sireniki (46.9 t/ha), Dieticheskiy (46.1 t/ha), Nadezhda (46.0 t/ha), Podmoskovniy (44.4 t/ha), Vylgortskiy (37.5 t/ha), Blank Brekos (33.1 t/ha), as well as five varieties of late leaf wilting: Spindle (43.9 t/ha), Korenevskiy (42.9 t/ha), Interes 21 (35.5 t/ha), Interes (27.1 t/ha), and Novost VIRa (25.2 t/ha). These data confirm that it is possible to achieve yields of Jerusalem artichoke tubers up to 54.2-58.5 t/ha [15].

To process tubers in August-September, it is preferable to use early Jerusalem artichoke varieties that, during this period, do not have time to grow and ratoon too much, and, hence, have a relatively even shape. However, at the end of October, for processing, it is preferable to use tubers of late varieties because they have already gained weight and have a mostly even shape, whereas the tubers of early varieties have already overgrown and have yeast covers that complicate their washing and peeling. 


\subsection{Value of Jerusalem Artichoke as a Forage Crop}

One of the main objectives of agriculture development is the increase in worldwide forage production. Fodder production is certain to be a fundamental branch of agriculture. [40-45]. In feeding Jerusalem artichoke tubers and herbage to animals, it was found that these types of feed were highly attractive for all kinds of animals and preferred over other types of forage [1,46-50].

Tubers are considered to be excellent succulent feed in early spring and autumn, so they are widely used in the cattle diet. Being rich in easily hydrolysable carbohydrates, mainly sugars, they provide animals with energy. The introduction of Jerusalem artichoke tubers in cows' diet increases milk yield by $4-5 \mathrm{~kg} /$ day after 5-6 days of feeding, and use of tubers as succulent feed for young animals significantly increases weight gain [43]. Jerusalem artichoke herbage and raw washed tubers are used as feed for domestic rabbits [45].

Analyzing the obtained data, it can be noted that, at the end of October, the herbage yield of all early Jerusalem artichoke varieties decreased by $0.5-20.7 \mathrm{t} / \mathrm{ha}$ due to the complete or almost complete drying of the aboveground part of the plant. Dry or almost dry crop tops can be used for animal feeding.

According to the nutritional value of the herbage feed in megajoules of metabolizable energy (Table 3) per 1 hectare, at the beginning of September, the following early varieties were distinguished: Nadezhda (32.9 K MJ), Skorospelka (29.3 K MJ), and Blank Brekos $(27.1 \mathrm{~K} \mathrm{MJ})$. Among the late varieties, the highest nutritional value was found in the following varieties: Novost VIRa (67.7 K MJ) and Spindle (62.3 K MJ).

According to the total nutritional value per $1 \mathrm{ha}$, the following varieties were the most suitable for fodder production: Novost VIRa (97.3 K MJ), Nadezhda (84.4 K MJ), Korenevskiy (92.8 K MJ), and Spindle (103.4 K MJ).

It should be noted that varieties of early leaf wilting have predominance of the tuber mass in the structure of the total feed value, whereas herbage mass prevails in varieties of late leaf wilting (Figure 3). The results obtained confirmed K.P. Danilov's recommendations for Jerusalem artichoke cultivation under conditions of the Chuvash Republic and the Upper Volga region. To achieve both a high yield of tubers and vegetation conservation, harvesting of herbage mass should be carried out in mid-September, and harvesting of tubers should be undertaken in early October $[12,51]$.

\subsection{Tuber Property Analysis of Jerusalem Artichoke Varietal Resources}

There are several types of Jerusalem artichoke tuber shape; for example, tubers of the varieties Vylgortskiy, Kaluzhskiy, and Sireniki are elongated; pear-shaped tubers can be found in the varieties Novost VIRa and Spindle; round-pear-shaped tubers are natural for Nakhodka, Podmoskovniy, and Blank Brekos; round-oval tubers are often found in the varieties Interest, Interest-21, Korenevskiy, Nadezhda, Tadzhikskiy, and Violet de Rense; and the tubers of Skorospelka variety are often rounded.

According to the surface indicator, the following varieties with smooth skin have been noted to be the most suitable for cultivation: Vylgortskiy, Dieticheskiy, Korenevskiy, Nadezhda, Nakhodka, Podmoskovniy, Tadzhikskiy, and Blank Brekos. Varieties with a smooth-bumpy skin surface partially meet the requirements; these are Kaluzhskiy, Novost VIRa, Sireniki, Skorospelka, and Spindle. The varieties with a bumpy-smooth skin surface, such as Interes, Interes 21, and Violet de Rense, may be more energy intensive with mechanized peeling.

Skin colors ranging from beige to brown were found in all varieties, except Tadzhikskiy (which has a reddish-light brown skin) and Violet de Rense (the tuber skin of this variety usually has a red-crimson color).

Tubers of the varieties Interes and Spindle were found to be most elongated (leggy), and about 98-107 mm long (Figure 4).

Regarding the indicator of the outermost transverse diameter, it should be mentioned that, in the first ten-day period of September, not all varieties had tubers of at least $30 \mathrm{~mm}$. Tubers of Skorospelka were found to be the largest, having a diameter of more than $45 \mathrm{~mm}$. 
According to morphological characteristics, the most suitable varieties for fresh tuber consumption, culinary purposes, and processing were Korenevskiy, Nakhodka, Skorospelka, and Blank Brekos.

When Jerusalem artichoke tubers were harvested early, the morphological characteristics of the following varieties fully met the requirements for fresh tuber consumption, culinary purposes, and processing: Korenevskiy, Nakhodka, and Blank Brekos. Among the varieties meeting the requirements almost completely were Skorospelka, Podmoskovniy, Tadzhikskiy, Nadezhda, and Dieticheskiy.

Recyclability depends on a number of parameters, including the dry matter content. Jerusalem artichoke tubers contain up to $19-30 \%$ of dry matter, $15-20 \%$ of which is watersoluble sugars. Jerusalem artichoke tubers are also equal to potatoes in terms of nutritional value [18]. When planted on saline soils in Uzbekistan within the optimal spring period, the dry matter content in the Jerusalem artichoke tubers was $21.7-22.1 \%$, depending on the variety studied [52].

The requirements for dry matter content during early harvesting (Figure 6) correspond to the samples of the varieties Korenevskiy (25.4\%), Novost VIRa (26.4\%), and Blank Brekos (25.0\%). The tubers of the following varieties gained a little less dry matter: Dieticheskiy (24.0\%), Interes (24.5\%), Interes $21(24.7 \%)$, Kaluzhskiy (24.7\%), Nadezhda $(24.3 \%)$, Podmoskovniy (24.5\%), and Sireniki $(24.8 \%)$.

Samples of varieties meeting the requirement for inulin content during early harvesting were: Dieticheskiy (14.7\%), Kaluzhskiy (18.7\%), Korenevskiy (15.0\%), Nakhodka (14.1\%), Novost VIRa (15.8\%), and Blank Brekos (16.7\%).

Being rich in DM, amino acids, and carbohydrates, and low in fiber content, Jerusalem artichoke herbage can be considered to be a source of high-energy feed exceeding the nutritional value of legumes and corn [40].

A nitrate content of below $250 \mathrm{mg} / \mathrm{kg}$ was found in the following varieties: Vylgortskiy (158), Dieticheskiy (230), Interes (200), Interes 21 (121), Kaluzhskiy (208), Nakhodka (208), Sireniki (238), and Spindle (244). It was also noticed that a significantly lower nitrate content was accumulated in the part of the tuber closest to the base (stolon).

When examining tubers for disease incidence after harvesting, no diseases were found.

Analyzing the data on the quality of the flesh of raw Jerusalem artichoke tubers, it can be noted that, in terms of flesh hardiness, all varieties met the requirements for raw tuber consumption and culinary purposes. Flesh browning (after 3 and $24 \mathrm{~h}$ ) was not observed in any variety.

In terms of flesh sweetness, the most suitable varieties (with the highest point) were: Vylgortskiy, Dieticheskiy, Nadezhda, Nakhodka, and Blank Brekos.

According to flesh juiciness, the most suitable varieties were: Vylgortskiy, Dieticheskiy, Korenevskiy, Nadezhda, Nakhodka, Podmoskovniy, Tadzhikskiy, Blank Brekos, Violet de Rense, and Spindle.

Pleasant odor characteristics of Jerusalem artichoke, without any foreign smells, appeared in the following varieties: Interes 21, Korenevskiy, and Violet de Rense.

The raw flesh of the varieties Dieticheskiy, Nadezhda, and Nakhodka was found to have high taste qualities. Good taste was noted in the following varieties: Vylgortskiy, Interes, Interes 21, Korenevskiy, Podmoskovniy, Sireniki, Blank Brekos, and Violet de Rense (Figure 7).

\subsection{Economic and Energy Efficiency of Jerusalem Artichoke Production for Foodstaff and Processing}

Long-term benefits of any technology are determined by its economic efficiency [53]. It should be emphasized that Jerusalem artichoke cultivation and production efficiency in the contemporary context is of particular importance because it is a new and promising crop. According to the technological map for 1-ton production of Jerusalem artichoke for food and processing, with a $75 \mathrm{~cm}$ row spacing cultivation scheme, the fixed asset costs were RUB 1366.3, diesel fuel consumption was $7.4 \mathrm{~L}$, gasoline consumption was $0.25 \mathrm{~L}$, and 
electricity consumption was $6.0 \mathrm{~kW}$. The labor cost of machine operators was 2.7 man-hours, that of drivers was 0.6 man-hours, and that of agriculturists was 3.4 man-hours.

In the calculation of the energy efficiency of Jerusalem artichoke varieties, it is necessary to take into account the yield obtained both of tubers and herbage. The latter is a source of high-quality animal feed and a complete green manure.

The analysis of the main energy assessment indicators of Jerusalem artichoke tubers demonstrated that, when growing varieties of early leaf wilting (compared with growing varieties of late leaf wilting), an average increase in energy consumption of $5.9 \mathrm{MJ} / \mathrm{ha}$ resulted in average growth in energy received of $18.5 \mathrm{MJ} / \mathrm{ha}$. The energy efficiency ratio (the ratio of energy received to energy expended) improved by an average of 0.4 .

The analysis of the main energy assessment indicators of Jerusalem artichoke herbage showed that, when growing early varieties (compared with growing late varieties), the amount of energy obtained was lower (on average by $20.4 \mathrm{MJ} / \mathrm{ha}$ ).

Despite its low tuber yield, the highest total energy efficiency coefficient of 3.09 was obtained in the Novost VIRa variety because this variety had the highest herbage yield. The varieties of Tadzhikskiy (2.78), Spindle (2.68), and Korenevskiy (2.43) had slightly lower total energy efficiency coefficients.

This research found that the total energy costs for carrying out operations during Jerusalem artichoke cultivation were $27.4-41.3 \mathrm{~K} \mathrm{MJ} / \mathrm{ha}$, although it is possible to achieve a total of 37.0-103.4 K MJ/ha (Figure 8).

The highest total coefficients among early varieties were found in Nadezhda (2.14), Blank Brekos (2.00), and Skorospelka (1.98).

Therefore, from the perspective of energy efficiency, the most profitable Jerusalem artichoke varieties grown for tubers were Nakhodka (1.37), Dieticheskiy (1.34), and Nadezhda (1.30).

\section{Conclusions}

1. The gross tuber yield of varieties with early leaf wilting was $33.1-51.1 \mathrm{t} / \mathrm{ha}$, whereas that of varieties of late leaf wilting was 14.4-43.9 $\mathrm{t} / \mathrm{ha}$, including the five late varieties Spindle, Korenevskiy, Interes 21, Interes, and Novost VIRa, which had yields of $25.2-43.9 \mathrm{t} / \mathrm{ha}$.

2. The study showed that, for the consumption of fresh tubers at the end of August and the beginning of September, it is preferable to grow varieties with early leaf wilting. On the contrary, for application of Jerusalem artichoke tubers at the end of October, late varieties are more appropriate because tubers have already gained weight and their shapes are more even. Being harvested in late August-early September, early varieties produced, on average, $69 \%$ of marketable tubers (with a diameter more than $30 \mathrm{~mm}$ ), whereas the marketable tuber yield of the late varieties was only $48 \%$. For harvesting in the third ten-day period of October, the proportion of marketable tubers in the "early" varieties was $82 \%$, and in the varieties with late leaf wilting it was $65 \%$.

3. The data obtained showed that it is possible to achieve a total yield of raw Jerusalem artichoke biomass of 36.8-98.1 t/ha. Moreover, in varieties of early leaf wilting, the mass of tubers prevailed in the structure of the total nutritional value of the feed $(68 \%)$, and in varieties with late leaf wilting, the herbage mass was predominant (59\%).

4. The highest DM content in tubers during early harvesting was found in the varieties Korenevskiy, Novost VIRa, and Blank Brekos (25.0-26.4\%); the content of inulin was highest in the varieties Diyeticheskiy, Kaluzhskiy, Korenevskiy, Nakhodka, Novost VIRa, and Blank Brekos (14.1-18.7\%). The raw flesh of the varieties Diyeticheskiy, Nadezhda, and Nakhodka was determined to have high taste qualities. Good taste qualities were noted in the varieties Vylgortskiy, Interes, Interes 21, Korenevskiy, Podmoskovniy, Sireniki, Blank Brekos, and Violet de Rense.

5. Jerusalem artichoke production required $27.4-41.3 \mathrm{~K} \mathrm{MJ} /$ ha of total energy for the necessary work, whereas it is possible to obtain a total of 37.0-103.4 K MJ/ha from growing Jerusalem artichoke. Late varieties with the largest total energy efficiency 
coefficient were: Novost VIRa (3.09), Tadzhikskiy (2.78), and Spindle (2.69); among early varieties were: Nadezhda (2.14), Blank Brekos (2.00), and Skorospelka (1.98).

6. Jerusalem artichoke seems to be a flexible crop that can grow on various soils and under different climatic conditions. In addition, it appears likely to be one of the most promising crops, the cultivation of which is energetically feasible. The research highlights the most future-proof varieties for cultivation in the Central Federal District of the Russian Federation, and the following varieties Nakhodka, Skorospelka, and Novost VIRa can be recommended.

Author Contributions: Conceptualization, A.A.M., A.S.D., T.P.K. and V.I.S.; Data curation, A.S.D. and V.I.S.; Formal analysis, T.P.K. and V.I.S.; Investigation, A.A.M., A.S.D. and T.P.K.; Methodology, A.A.M. and T.P.K.; Project administration, A.A.M.; Resources, A.S.D. and V.I.S.; Software, T.N.F.; Supervision, A.A.M.; Validation, T.P.K. and V.I.S.; Visualization, T.N.F.; Writing-original draft, A.A.M., A.S.D. and T.P.K.; Writing-review \& editing, A.A.M. and T.N.F. All authors have read and agreed to the published version of the manuscript.

Funding: This research received no external funding.

Data Availability Statement: The data is contained within the article.

Acknowledgments: This article was supported by the Ministry of Science and Higher Education of the Russian Federation in accordance with agreement № 075-15-2020-905 of 16 November 2020 for providing a grant in the form of subsidies from the Federal budget of the Russian Federation. The grant was provided for state support for the creation and development of a World-class Scientific Center "Agro technologies for the Future".

Conflicts of Interest: The authors declare no conflict of interest.

\section{References}

1. Korolev, D.D. Potatoes and JERUSALEM ARTICHOKE-Products of the Future; Korolev, D.D., Simakov, E.A., Starovoitov, V.I., Eds.; FSNU “Rosinformagroteh": Moscow, Russia, 2007; p. 292.

2. Anikienko, T.I. Chemical and Trace Element Composition of Tubers and Herbage of Jerusalem Artichoke; Anikienko, T.I., Ed.; Bulletin of KrasSAU: Krasnoyarsk, Russia, 2008; pp. 76-80.

3. Zelenkov, V.N. Jerusalem Artichoke (Earth Apple) a Promising Multi-Purpose Crop; Zelenkov, V.N., Kochnev, N.K., Shelkova, T.V., Eds.; Novosibirsk: Aris, Korea, 1993; p. 36.

4. Mezencev, R. Premiers Resultats des Essais 1984 AZF/AFME Sur Topinambours/Betteraves en Midi-Pyrenees; Mezencev, R., Ed.; Premiers Resultats des Essais 1984 AZF/AFTER sur Topinambours/Betteraves en Midi-Pyrenees. AZF/CdF Chimie: Toulouse, France, 1985; p. 26.

5. Ilchenko, S.M. Market Conjuncture of Jerusalem Artichoke and Products of Its Processing; Ilchenko, S.M., Yu, O., Eds.; Bulletin of the Omsk State Agrarian University: Omsk, Russia, 2016; pp. 261-266.

6. Mimiola, G. Test of topinambour cultivation in Southern Italy. In Topinambour (Jerusalem Artichoke); Mimiola, G., Grassi, G., Gosse, G., Eds.; Commission of the European Communities: Luxembourg, 1988; pp. 53-60.

7. Schittenhelm, S. Agronomic performance of root chicory, Jerusalem artichoke, and sugarbeet in stress and nonstress environments. Crop Sci. 1999, 39, 1815-1823. [CrossRef]

8. Starovoitov, V.I.; Starovoitova, O.A.; Aldoshin, N.; Manokhina, A.A. Technology and mechanization of cultivation of Jerusalem artichoke healthier. Res. Agric. Eng. 2018, 64, 151-156.

9. Zhuchkova, M.A. Jerusalem Artichoke-a Plant of the XXI Century; Zhuchkova, M.A., Skripnikov, S.G., Eds.; Federal Scientific Center of Vegetable Growing Vegetables of Russia: Moscow, Russia, 2017; pp. 31-33.

10. Zhao, M.; Zhong, Q.; Tian, M.; Han, R.; Ren, Y. Comparative transcriptome analysis reveals differentially expressed genes associated with the development of Jerusalem artichoke tuber (Helianthus tuberosus L.). Ind. Crops Prod. 2020, 151, 112455. [CrossRef]

11. Zorić, M.; Terzić, S.; Sikora, V.; Brdar-Jokanović, M.; Vassilev, D. Effect of environmental variables on performance of Jerusalem artichoke (Helianthus tuberosus L.) cultivars in a long term trial: A statistical approach. Euphytica 2017, 213, 1-14. [CrossRef]

12. Koroleva, Y.S. Accumulation of herbage and tuber yields under the Upper Volga region conditions. Digitalization in the agroindustrial complex: Technological resources, new opportunities and challenges of time. In Proceedings of the scientific works on the materials of the International Scientific and Practical Conference, Tver State Agricultural Academy, Tver, Russia, 11-13 February 2020; pp. 15-19.

13. Krivoshapkin, K.K. Topinambour-a Promising Feed and Food Crop for Yakutia; Krivoshapkin, K.K., Lukin, F.A., Eds.; Academic Bulletin of the Yakut State Agricultural Academy: Yakutsk, Russia, 2020; pp. 29-36. 
14. Safarmadi, M. The Productive Potential of Topinambour (Heliautus tuberosus L.) under the Conditions of Tajikistan; Safarmadi, M., Partoev, K., Nikhmonov, I.S., Eds.; Izvestia Orenburg SAU: Orenburg, Russia, 2020; pp. 82-85.

15. Usanova, Z.I. Productivity of Topinambour Varieties with Different Standing Densities; Usanova, Z.I., Fridman, Y.A., Pavlov, M.N., Eds.; Dairy Business Gazette: Vologda, Russia, 2020; pp. 146-155.

16. Barloy, J. Synthesis on Jerusalem Artichoke Projects, In Topinambour (Jerusalem Artichoke); Barloy, J., Fernandez, J., Grassi, G., Gosse, G., Eds.; Report EUR 13405; Commission of the European Communities: Luxembourg, 1991; pp. 3-14.

17. Skoblina, V.I. (Ed.) Jerusalem Artichoke; Armada Press: Moscow, Russia, 2001; p. 36.

18. Revnivtsev, P.V. Jerusalem Artichoke (Heliautus tuberosus)-an Innovative Crop of Multipurpose Application; Revnivtsev, P.V., Vedina, Y.V., Eds.; Young scientists-to agriculture: A proceedings of the student conference 11-12 April 2017; Saratov State Agrarian University: Saratov, Russia; Penza State Agrarian University: Penza, Russia, 2017; pp. 21-25.

19. Zubr, J. Characteristics of Growth and Development of Different Jerusalem Artichoke Cultivars; Zubr, J., Pedersen, H.S., Fuchs, A., Eds.; Inulin and Inulin-Containing Crops, Elsevier Science: Amsterdam, The Netherlands, 1993; pp. 11-19.

20. Starovoytov, V.; Starovoytova, O.; Aldoshin, N.; Manohina, A. Jerusalem artichoke as a means of fields conservation. Acta Technol. Agric. 2017, 20, 7-10. [CrossRef]

21. Yaroshevich, M.I.; Vecher, N.N.; Gorny, A.V. Theoretical and applied aspects of plant introduction as a promising direction in the development of science and of the national economy. In Proceedings of the International Scientific Conference dedicated to the 75th Anniversary of the Establishment of the Central Library System of the National Academy of Sciences of Belarus, Minsk, Belarus, 12-15 June 2007; pp. 323-325.

22. Morrenhof, H. Aardpeer, een Potentieel Nieuw Gewas-Teeltonderzoek; Morrenhof, H., Bus, C.B., Eds.; Verslag 99, Research Station for Arable Farming and Field Production of Vegetables (PAGV): Lelystad, The Netherlands, 1990; p. 25.

23. Moshou, D. Automatic detection of 'yellow rust' in wheat using reflectance measurements and neural networks. Comput. Electron. Agric. 2004, 44, 173-188. [CrossRef]

24. Manokhina, A.A.; Starovoitova, O.A.; Starovoitov, V.I. Improving the technological process for the mini-tubers production of the original seed of Jerusalem artichoke. In Proceedings of the IOP Conference Series: Earth and Environmental Science, Surabaya, Indonesia, 21-22 August 2019; p. 012091.

25. Barloy, J. Jerusalem artichoke tuber diseases during storage. In Topinambour (Jerusalem artichoke); Barloy, J., Grassi, G., Gosse, G., Eds.; Commission des Communautes Europeennes: Madrid, Spain, 1988; pp. 145-149.

26. Modler, H.W.; Jones, J.D.; Mazza, G. The effect of long-term storage on the fructo-oligosaccharide profile of Jerusalem artichoke tubers and some observations on processing. In Inulin and Inulin-Containing Crops; Fuchs, A., Ed.; Elsevier: Amsterdam, The Netherlands, 1993; pp. 57-64.

27. Yamaguchi, M. World Vegetables: Principles Production and Nutritive; Yamaguchi, M., Ed.; Ellis Horwood: Chichester, UK, 1983; pp. 163-164.

28. Viriyasuthee, S.; Jogloy, W.; Saksirirat, S.; Saepaisan, M.L.; Gleason, R.S. Chen Biological control of alternaria leaf spot caused by alternaria spp. Jerusalem artichoke (Helianthus tuberosus.) under two fertilization regimes. Plants 2019, 8, 463. [CrossRef] [PubMed]

29. MacKerron, D.K.L. Decision Support Sistems in Produchon: Bringing Models to Practice; MacKerron, D.K.L., Haverkort, A.J., Eds.; Wageningen Academic Publishers: Wageningen, The Netherlands, 2004; p. 238.

30. Schneider, S.M. Mapping of Potato Yield and Quality; Schneider, S.M., Boydston, R.A., Han, S., Evans, R.G., Eds.; Springer Science+Business Media B.V., Formerly Kluwer Academic Publishers B.V.: Dordrecht, The Netherlands, 1997; Volume I, pp. $253-261$.

31. Schorr-Galindo, S. Sugar potential of different Jerusalem artichoke cultivars according to harvest. Biores. Tech. 1997, 60, 15-20. [CrossRef]

32. Zhorovin, N.A. (Ed.) Growing Conditions and Consumer Qualities of Potatoes; Uradzhai Minsk: Minsk, Belarus, $1977 ;$ p. 94.

33. Dospekhov, B.A. Field Experiment Technique (with The Basics of Statistical Processing of Research Results), 5th ed.; Armor, B.A., Ed.; Agropromizdat: Moscow, Russia, 1985; p. 351.

34. Starovoitov, V.I. Program and Methodology for Evaluating Jerusalem Artichoke Varieties in Test Nurseries within The Framework of The Union State Program "Innovative Development of Potatoes and Jerusalem Artichoke" for 2014-2016; Starovoitov, O.A., Starovoitova, Y.P., Boyko, Y.A., Masyuk, S.D., Kiru, M.I., Yaroshevich, B.M., Eds.; SNU VNIIKH Russian Agricultural Academy: Moscow, Russia, 2014; p. 6.

35. FSBI. State Committee for Breeds and Varieties, Test procedure for distinctness, uniformity and stability; No. 12-06/82; State Commission of the Russian Federation for Testing and Protection of Breeding Achievements: Moscow, Russia, 2012.

36. Methodology for Determining The Economic Efficiency of The Use in Agriculture of The Results of Scientific Research and Development Work, New Technology, Inventions and Rationalization Proposals; VNIIPI, M. (Ed.) Ministry of Agriculture of the USSR VASKHNIL: Moscow, Russia, 1983; p. 149.

37. Litun, B.P. Bioenergy Assessment Methodology in Potato Growing; Litun, B.P., Vniikh, M., Eds.; Russian Agricultural Academy: Moscow, Russia, 2000; p. 30.

38. Berzhanova, M.I. Cultivation of Girasol in The Conditions of the Atyrau Region; Current scientific research in the modern world; Berzhanova, M.I., Ed.; Institute of Social Transformation: Pereyaslav-Khmelnitsky, Ukrain, 2019; pp. 116-121.

39. Ruban, G.A. Topinambour as a Perennial Crop in the North (Komi Republic); Ruban, G.A., Zainullina, K.S., Mikhovich, J.E., Eds.; Bulletin of the Botanical Garden of Saratov State University: Saratov, Russia, 2019; pp. 212-224. 
40. Kotova, Z.P. Evaluation of the fodder value of Jerusalem artichoke (Heliantus tuberosus L.). In Conditions of Karelia; Kotova, Z.P., Parfenova, N.V., Eds.; Feed Production: St. Petersburg, Russia, 2015; pp. 41-45.

41. Kolomeichenko, V.V. Feed Production: Textbook; Kolomeichenko, V.V., Ed.; Lan: St. Petersburg, Russia, $2015 ;$ p. 656.

42. Mass Analysis of Feed: A Reference Book; Razumov, V.A. (Ed.) Moscow Kolos: Moscow, Russia, 1982; p. 176.

43. Yashchuk, M.A. Jerusalem Artichoke-Raw Materials for The Production of Animal Feed; Yashchuk, M.A., Solovieva, E.V., Eds.; News of Higher Educational Institutions, Food Technology, Kuban State Technological University Krasnodar: Krasnodar, Russia, 2007; pp. 57-58.

44. Pazin, M.A.; Kuznetsov, Y.V. Modern trends in agricultural production in the world economy. In Proceedings of the XVIII International Scientific and Practical Conference, Kemerovo, Russia „, 3-4 December 2019; Kuzbass State Agricultural Academy: Kemerovo, Russia, 2019; pp. 78-82.

45. Khaziakhmetov, F.S. Rational Feeding of Animals: A Tutorial, 3rd ed.; Khaziakhmetov, F.S., Ed.; Lan: St. Petersburg, Russia, 2019; p. 364. Available online: https:/ / e.lanbook.com/book/115666 (accessed on 5 August 2021).

46. Anikienko, T.I. (Ed.) Chemical Composition and Nutritional Value of Jerusalem Artichoke Herbage and Tubers in Comparison with Other Crops; Publishing House Academy of Natural Sciences LLC: Moscow, Russia, 2015; pp. 278-282.

47. Dzhaboeva, A.S. Biochemical Composition of Jerusalem Artichoke; Dzhaboeva, A.S., Shaova, L.G., Eds.; Kuban State Technological University: Krasnodar, Russia, 2016; pp. 648-653.

48. Tsuglenok, N.V.; Tsuglenok, G.I.; Anikienko, T.I. High-Energy Forage Crop Jerusalem Artichoke in The Fodder Production of The Krasnoyarsk Territory; Bulletin of Krasnoyarsk SAU: Krasnoyarsk, Russia, 2007; pp. 127-130.

49. Mikhalchenkova, E.S. Jerusalem Artichoke as A Promising Fodder Crop in The Non-Black Earth Zone of Russia; Mikhalchenkova, E.S., Ed.; Bulletin of Orel SAU: Orel, Russia, 2009; pp. 42-43.

50. Tsgoeva, T.E. Chemical Analysis of Jerusalem Artichoke Varieties Skorospelka and Interes; Izvestiya Gorskogo SAU: Vladikavkaz, Russia, 2011; pp. 280-282.

51. Danilov, K.P. The Influence of The Harvesting Period on The Yield of Leaf-Stem Mass and The Collection of Jerusalem Artichoke Tubers; Danilov, K.P., Shchiptsova, N.V., Eds.; Agronomy and Forestry: Orenburg, Russia, 2015; pp. 34-36.

52. Zhangabaeva, A.S. The Influence of Elements of Agricultural Technology on The Yield of Jerusalem Artichoke under The Conditions of Karakalpakstan; International scientific review; Zhangabaev, A.S., Mavlyanova, R., Eds.; International scientific Review Olympus: Ivanovo, Russia, 2017; pp. 15-17.

53. Zvyagintsev, P.S. (Ed.) Problems of Assessing The Efficiency of Investments and Innovations; Russian Academy of Sciences, Institute of Economics (RAS IE): Moscow, Russia, 2010; p. 366. 